\title{
Impacts of Climate Change and Hydrological Hazards on Monsoon Crop Patterns in the Lesser Himalaya: A Watershed Based Study
}

\author{
Pradeep K. Rawat* \\ Department of Geography, Kumaun University Nainital, 263002, India
}

\begin{abstract}
The Lesser Himalaya region is a densely populated, nonglacial tract of the Himalaya. About 95 percent of the regional population depends on agriculture and forest resources but both have been declining rapidly in recent decades due to climate change and hydrological hazards. The main objective of this study was to assess the integrated impacts of climate change and hydrological hazards on monsoon crop patterns in the Lesser Himalaya through a geographic information system (GIS) database management system (DMS). The DMS comprises four GIS modules: climate informatics, land use informatics, hydro-informatics, and agro-informatics. The Dabka watershed in India's Uttarakhand State is part of the Kosi Basin in the Lesser Himalaya in District Nainital and was chosen as a case study. The climate of the study area, depending on elevation, falls into three climatic zones: subtropical, temperate, and moist temperate, which are favorable for mixed forest, pine forest, and oak forest respectively. The results of the climate-informatics analysis suggest that in recent decades all these climatic zones have shifted towards higher altitudes and the areas of oak and pine forests have decreased. Forest degradation has accelerated hydrological hazards (high runoff, flash floods, river-line floods, soil erosion, and landslides) in monsoon periods, which affected about 22 percent of the cultivated land annually in 2005-2010. Monsoon crop yields decreased by an annual average of 1.40 percent between 1985 and 2010 while the population of the study area increased by an average of 2 percent each year in the same period. The negative correlation between annual crop yields and population growth has led to increased food security risks.
\end{abstract}

Keywords climate change, Himalaya, hydrological hazards, land use change, monsoon crops

\section{Introduction}

The Intergovernmental Panel on Climate Change-IPCC (2001, 2007a, 2007b) warns that the progress in human development achieved may be slowed down or even reversed by climate change, as new threats emerge to food and

\footnotetext{
* E-mail: geopradeep@hotmail.com
}

livelihood security, agricultural production and access, and nutrition and public health. Agriculture constitutes the backbone of most developing economies throughout the world and food and fiber production is essential for sustaining and enhancing human welfare (Rosenzweig and Parry 1994; Fischer et al. 1996, 2005; Tao et al. 2006; Lobell and Burke 2010). By 2080, agricultural output in developing countries may decline by 20 percent due to climate change, while output in industrial countries is expected to decrease by 6 percent (Cline 2007). For the poor, agricultural production is both a source of food and a source of income (Howden et al. 2007; Schmidhuber and Tubiello 2007). Consequently, agriculture has been a most important concern in the discussions on climate change. Agronomic and economic impacts from climate change depend primarily on two factors: (1) the rate and magnitude of change in climate attributes and the agricultural effects of these changes; and (2) the ability of agricultural production to adapt to changing environmental conditions (Challinor et al. 2003, 2005, 2007, 2009).

Temperature, precipitation, atmospheric carbon dioxide content, the incidence of extreme events, and sea level rise are the main climate change related drivers that impact agricultural production (Adams et al. 1998; Lobell and Field 2007). Climate change is considered as the greatest threat to agriculture and food security in the twenty-first century, particularly in many of the poor, mountainous agriculture-based countries with their low capacity to cope effectively (Adams et al. 1995; Darwin and Kennedy 2000). Mountain agriculture is already under stress as a result of population increase, industrialization and urbanization, competition over resource use, degradation of resources, and insufficient public spending on rural infrastructure and services (Easterling 1996; Darwin 1999). The impact of climate change and tremendous hydrological hazards (drought, river-line floods, flash floods, erosion, rain induced landslides, and so on) is likely to exacerbate these stresses even further (Kostrowicki 1983; Hamilton 1987; Scheling 1988; Tiwari 2000). The outlook for the coming decades is that agricultural productivity needs to continue to increase and will require more water to meet the demands of growing populations (Rosenzweig and Parry 1994; Schlenker, Hanemann, and Fisher 2006). Ensuring impartial 
access to water and its benefits now and for future generations is a major challenge as scarcity and competition increase. The amount of water allocated to agriculture and water management choices will determine, to a large extent, whether societies achieve economic and social development and environmental sustainability (Katz and Brown 1992; Easterling et al. 1993; Iglesias, Rosenzweig, and Pereira 2000).

Food security and rural livelihoods are intrinsically linked to water availability and use (Monteith 1981; Wheeler et al. 2000). Food security is determined by the options people have to secure access to agricultural production and exchange opportunities (Parry et al. 1999; Hansen and Jones 2000). These options are influenced by access to water. Making these water-livelihood linkages is important for a more complete understanding of the nature of the vulnerability of households to climate-related hazards such as drought, and the multifaceted impacts that water security has on food and livelihood security (Rawat et al. 2011). In order to highlight such linkages, there has been a move in recent years towards looking at water issues through sustainable livelihood frameworks (Rosenzweig et al. 1999).

One main feature of climate change adaptation at the local level is the attempt to increase the resilience of populations to climate-related hazards. This means assessing the populations at risk of water and food insecurity. First, lack of access to adequate water supplies, both in quality and quantity, for domestic uses can be a major cause of declining nutritional status and of disease and morbidity. Second, domestic water is often a production input. Such production is essential for direct household consumption and/or income generation. Third, the amount of time used to collect water, and related health hazards, can be immense, especially for women and girls, and has been well documented (Semenov and Porter 1995; Iglesias et al. 2007).

Previous studies often relate food security problems to decreasing trends of crop yields due to climate change. But the present study argues that food security problems are also caused by productivity loss of agricultural land through hydrological hazards accelerated by climate change. Climate change triggers hydrological hazards such as high runoff, flash floods, river-line floods, and non-seismic landslides, which cause community food availability risks in mountainous terrains (Ives 1989; Valdiya and Bartarya 1989; Cruz 1992; Jain, Kumar, and Varghese 1994; Sing 2006; Rawat et al. 2012). Although climate change and hydrological hazards affect all four key dimensions of food security - availability, stability, access, and utilization, the present study focuses only on the availability aspect of food for the local communities. This article reviews current knowledge about the relationships between climate change, hydrological hazards, and monsoon crop patterns in the Lesser Himalaya region because the annual food availability of this mountainous region completely depends on monsoon crops. Climate change and land degradation affect community food availability and livelihoods through accelerating hydrological hazards in monsoon periods.
The Dabka study watershed lies between 29'24'09'$29^{\circ} 30^{\prime} 19^{\prime \prime} \mathrm{E}$ and $79^{\circ} 17^{\prime} 53^{\prime \prime}-79^{\circ} 25^{\prime} 38^{\prime \prime} \mathrm{N}$ in the northwest of Nainital Township (Figure 1). It covers an area of about 69 $\mathrm{km}^{2}$ between 700 and $2623 \mathrm{~m}$ above the mean sea level. The absolute majority of the local population depends on agriculture and forest resources but the forest cover is decreasing at a rate of $0.36 \mathrm{~km}^{2}$ per year and agricultural production is also decreasing.

\section{Methodology}

The study comprised two main components: lab/desk study, and field investigations. The procedures adopted for this study are outlined in Figure 2, which depicts the study carried out through the GIS database management system (DMS). GIS-DMS is a set of computer programs for managing an integrated spatial and attribute database for tasks such as map and data input, storage, search, retrieval, manipulation, and output. Existing DMS is constituted of four different GIS modules consisting of spatial map layers with their attribute data. These four GIS modules are: climate informatics, land use informatics, hydro-informatics, and agro-informatics.

\subsection{Climate Informatics Module}

The climate informatics module consists of the spatial distribution of climatic parameters and their change through daily, monthly, and annual weather data (temperature, rainfall, humidity, and evaporation) of two study periods during 1985-1990 and 2005-2010. To determine the climate variability during the last twenty-five years, a comprehensive meteorological evaluation was carried out in this study for the period from 2005-2010 and the results were compared with a previous study for 1985-1990 (Bisht 1991) from the same study area - the Dabka watershed. Based on the meteorological data of both study periods, the climate of the study area is characterized as subtropical, temperate, and moist temperate at different elevations. These meteorological data were recorded at five meteorological stations. Four stations are located in the sample microwatersheds established at different elevations and run by the Geology and Geography Departments of Kumaun University, and one is located at a lower elevation of the study area, established and run by the Irrigation Department of the Uttarakhand State government. The four meteorological stations run by Kumaun University are funded by the government of India under its different agencies, including the Department of Environment that provided the 1985-1990 data and the Department of Science and Technology that provided the 2005-2010 data. The meteorological records for the study period of twenty-five years (1985-2010) indicate a lower average mean annual temperature of $17^{\circ} \mathrm{C}$ in $1985-1990$ whereas in $2005-2010$ the study area experienced a higher average mean annual temperature of $19^{\circ} \mathrm{C}$. Therefore 1990 was chosen as the base year to analyze climate variability and its impact on land use patterns. 


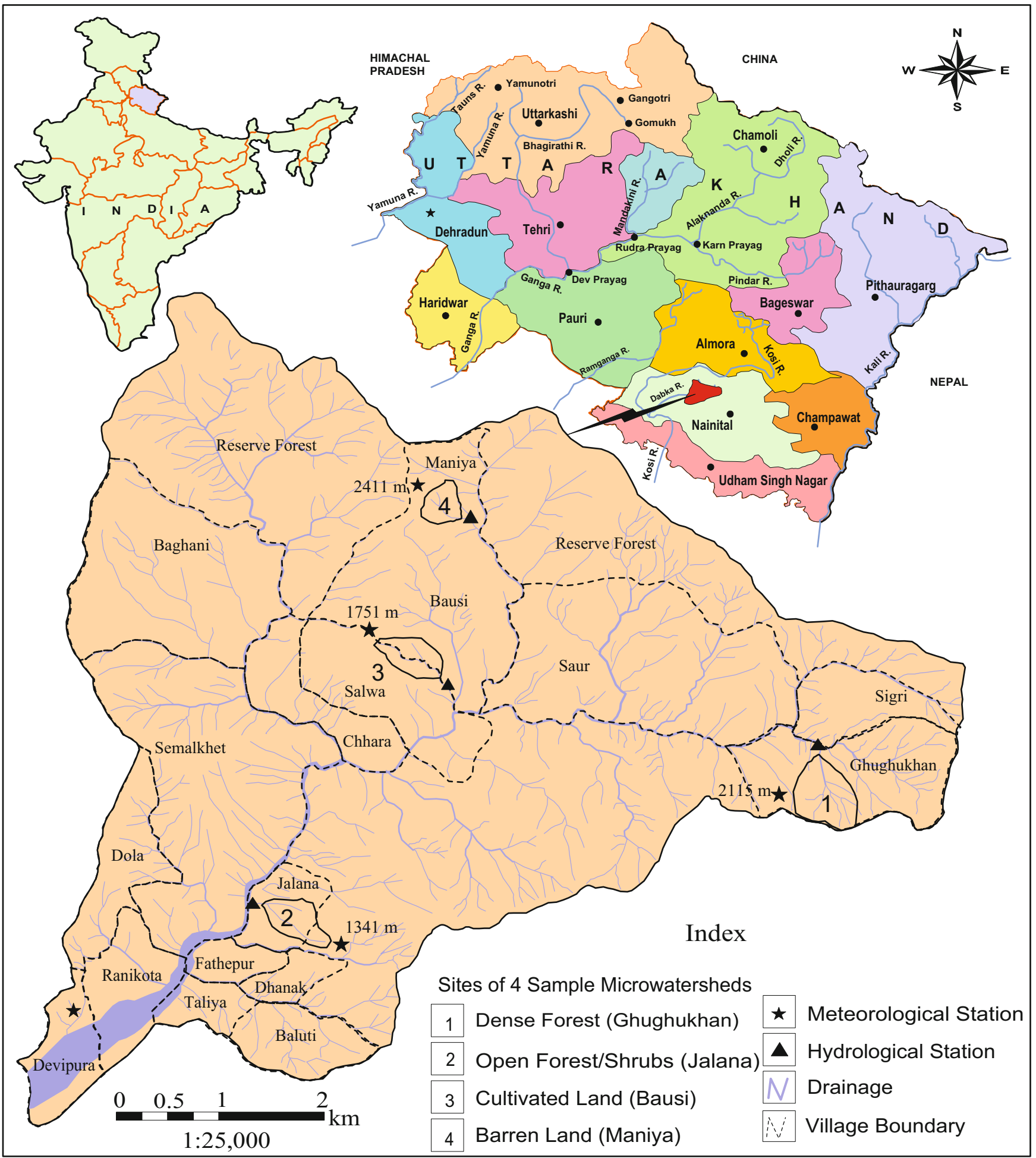

Figure 1. Location map of the Dabka watershed showing four sample microwatersheds with sixteen villages and hydrological and meteorological stations in the study area 


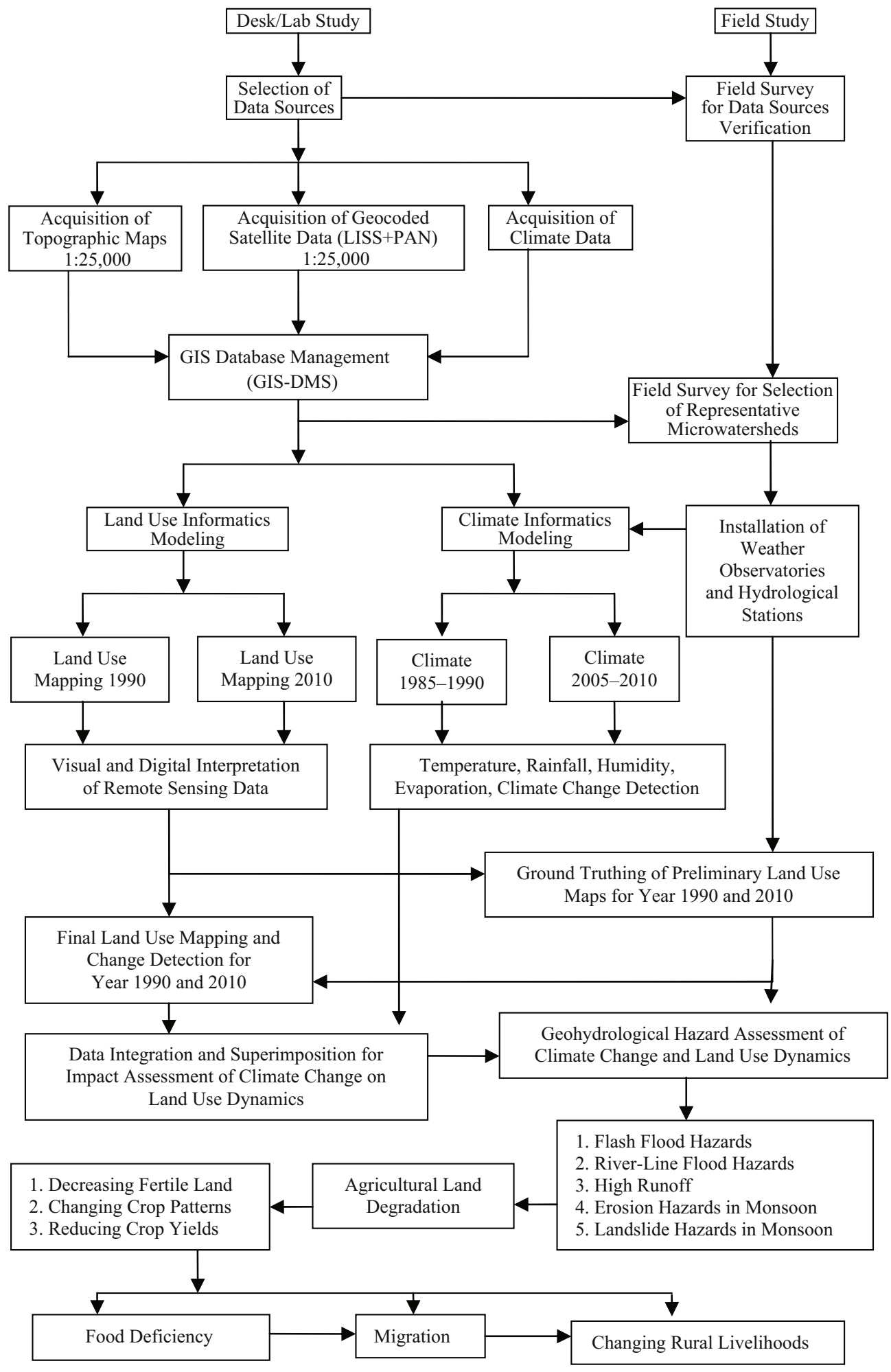

Figure 2. Procedures adopted for the study and causal factors between climate change and change in monsoon crop patterns and other impacts 
Using the elevations of each meteorological station, isotherms for 1985-1990 and 2005-2010 and spatial distribution of the climatic parameters are delineated, and the resulting spatial distribution maps are superimposed over the land use maps for 1990 and 2010 to assess the specific impact of climate change on particular categories of land use and land cover.

\subsection{Land Use Informatics Module}

The land use informatics module consists of decadal and annual change detection in the spatial distribution of land use types. Indian Remote Sensing Satellite (IRS-1C) LISS-III and PAN merged data of 1990 and 2010 were used for the analysis and mapping of land cover / land use for the respective years. Supplementary data and information required for the study have been generated from various primary as well as secondary sources. The primary information was generated through field surveys, mapping, interviews, and the secondary data were collected from various sources, such as the 2001 census of India, government agencies, land records, and forests maps. Radiometric corrections were done employing a dark pixel subtraction technique. The satellite images of the study area were registered geometrically using SOI Topographical Sheets $(56 \mathrm{O} / 7 \mathrm{NE}$ and $56 \mathrm{O} / 7 \mathrm{NW})$ of the area at the scale of 1:25,000. To carry out this important exercise uniformly, well distributed common Ground Control Points (GCPs) were selected and marked with the root mean square (RMS) error of one pixel and the images used were resampled by cubic convolution method. The LISS and PAN data were co-registered with the RMS error of 0.3 pixel and the output false color composite (FCC) images were transformed into intensity, hue, and saturation (IHS) color images. The reverse transformation from IHS to red, blue, and green (RBG) images was performed substituting the original highresolution image for the intensity component, along with the hue and saturation components from the original RBG images. This merge data product obtained through the fusion of IRS-1C LISS-III and PAN was used for the generation of land cover / land use maps of the study area for 1990 and 2010, and digital image processing techniques supported by intensive ground truth surveys were used for the interpretation of the remote sensing data. In order to enhance the interpretability of the remote sensing data for digital analysis, principal component analysis (PCA) was performed and normalized difference vegetation index (NDVI) images were generated. In the Himalayan mountain terrain the interpretability of the remote sensing data to a large extent is affected by the complexity of the terrain. Due to the effect of elevation and slope and aspect, the spectral signature of the same objects is often different and vice versa. In order to overcome these constraints and also to attain the best possible level of accuracy in the interpretation, intensive ground truth surveys were carried out in the study area and a visual interpretation key was developed for primary land cover / land use classification (Table 1). This was followed by the digital classification of land cover / land use through on-screen visual recording and rectification. To monitor the dynamics of land utilization patterns in the study area the land use maps generated for the years 1990 and 2010 were overlaid using GIS and land use changes were analyzed and mapped.

\subsection{Hydro-Informatics Module}

The hydro-informatics module consists of daily, monthly, and annual records of spring hydrology and stream hydrology of the study area. To assess the geohydrological impacts of climate change a comprehensive investigation was carried out for the groundwater table, spring discharge, and stream discharge throughout the study area during 2005-2010 and the results are compared with previous study for 1985-1990 (Bisht 1991).

\subsection{Agro-Informatics Module}

The agro-informatics module appraises the integrated impacts of climate change and hydrological hazards (drought, floods, soil erosion, and landslides) on food security through their negative impacts on the agricultural ecosystems, that is, reduced irrigation facilities, changing crop patterns, decreasing production rates, reduced livestock and milk production, and so on. This module's inputs were obtained through an extensive household survey and the modeling results were compared with village level census data of India for 1981 and 2011.

Table 1. Land use interpretation key for the Dabka watershed

\begin{tabular}{ll}
\hline Land Cover / Land Use Classes & Tone \\
\cline { 2 - 2 } Oak & $\begin{array}{l}\text { Red, bright red in the south aspects or gentle slopes, dull red and dull tar green in north and } \\
\text { steep slopes }\end{array}$ \\
Pine & Green in the north aspects, red in the south aspects or on ridges \\
Mixed Forests & Red interspersing with reddish and dull green \\
Cultivated Land & Reddish and yellowish \\
Shrub/Barren Land & Light cyan interspersing with reddish or yellowish in both the south and north aspects \\
Riverbeds and Water Bodies & Black and blackish \\
\hline
\end{tabular}

Source: Rawat, Tiwari, and Pant 2011. 


\section{Climate Variability, Land Use Dynamics, and Hydrological Hazards}

The pioneer climate change studies (Shrestha et al. 2000; Shrestha 2009; Singh et al. 2011) from different parts of the Himalaya suggest that the climatic zones have shifted towards higher altitudes due to global climate change, which affects the favorable conditions of the existing land use pattern. Consequently, climate change has accelerated several hydrological hazards during monsoon period, including flood runoff, soil erosion, landslides, and slope failure. These hydrological hazards lead to land degradation in the region, on forest land and cultivated land. The Kumaun Lesser Himalaya also experiences the same phenomena as the results of this research show.

\subsection{Trends of Climate Change in the Lesser Himalaya Region}

The climate informatics module consists of a comparative study of climatic parameters for a twenty-five year period from 1985 to 2010 to appraise the impacts of climate variability on land use patterns because climate change adversely influences the ecology of the watershed and elevates several environmental and socioeconomic risks through high runoff, erosion, and sediment transport during the rainy season. Monthly and annual climate records of two study periods are used to map the spatial distribution of the climatic parameters.

Temperature: The five-station and five-year average mean annual temperature of the Dabka watershed was $19^{\circ} \mathrm{C}$ in 2005-2010 and about $17^{\circ} \mathrm{C}$ in 1985-1990 (Table 2) although it varies by elevation throughout the study area. May is the driest and hottest month and has the highest temperature especially on south-facing barren land, whereas January is the coldest month and has the lowest temperature in the year. The average maximum annual temperature was $37^{\circ} \mathrm{C}$ in 2005-2010, whereas it was only $32^{\circ} \mathrm{C}$ in $1985-1990$. The average minimum annual temperature was $7^{\circ} \mathrm{C}$ in $1985-1990$, whereas it had gone down to $4^{\circ} \mathrm{C}$ by $2005-2010$. The climate data indicate increasing trends of extreme cold and hot weathers in the months of January and May. The average annual temperature increased about $2^{\circ} \mathrm{C}$ in $1985-2010$ at a rate of $0.10{ }^{\circ} \mathrm{C} \mathrm{a}^{-1}$.

Rainfall: In the 2005-2010 period, average annual rainfall within the watershed varied between $1623 \mathrm{~mm}$ at Maniya (on environmentally stressed barren hill slope) and $2187 \mathrm{~mm}$ at Ghughu (on dense forest hill slope), while it was $1969 \mathrm{~mm}$ at Bausi (on agricultural land), and $2086 \mathrm{~mm}$ at Jalna (on fairly dense forest / shrub land). Throughout the watershed the fivestation average annual rainfall was $1874 \mathrm{~mm}(156 \mathrm{~mm}$ per month) in 2005-2010, whereas during the 1985-1990 period it was $2120 \mathrm{~mm}$ (177 mm per month) (Table 2). The difference in temporal distribution of monthly rainfall between these two time periods suggests that the annual rainfall pattern has changed with a higher concentration of extreme rainfall in July and August, which increases the risk of hydrological hazards such as erosion, sediment transport, floods, landslides, and denudation. The rainfall records from twentyfive years indicate that the rainy season covers four months (June to September). In 1985-1990 average rainfall was higher in all months than in 2005-2010. The latter period was characterized by increasing drought events during non-monsoon months and heavier rainfall within short time periods during the monsoon months. Average annual rainfall decreased at a rate of $1.03 \mathrm{~mm} \mathrm{a}^{-1}$ (Table 2).

Table 2. Monthly and annual climatic parameters and change in the Dabka watershed

\begin{tabular}{|c|c|c|c|c|c|c|c|c|c|c|c|c|c|c|}
\hline \multirow{2}{*}{$\begin{array}{l}\text { Study } \\
\text { Periods }\end{array}$} & \multirow{2}{*}{$\begin{array}{l}\text { Meteorological } \\
\text { Parameters }\end{array}$} & \multicolumn{12}{|c|}{ Average Monthly Results } & \multirow{2}{*}{$\begin{array}{l}\text { Annual } \\
\text { Average }\end{array}$} \\
\hline & & Jan. & Feb. & Mar. & Apr. & May & Jun. & Jul. & Aug. & Sep. & Oct. & Nov. & Dec. & \\
\hline \multirow{4}{*}{$\begin{array}{l}\text { Existing } \\
(2005-2010)\end{array}$} & Temperature $\left({ }^{\circ} \mathrm{C}\right)$ & 4.00 & 10.00 & 16.00 & 24.00 & 37.00 & 27.00 & 24.00 & 23.00 & 21.00 & 20.00 & 14.00 & 12.00 & 19.00 \\
\hline & Rainfall (mm) & 12.00 & 69.00 & 76.00 & 12.00 & 76.00 & 262.00 & 486.00 & 566.00 & 261.00 & 31.00 & 13.00 & 9.00 & 156.00 \\
\hline & Humidity (\%) & 52.00 & 65.00 & 64.00 & 57.00 & 51.00 & 58.00 & 82.00 & 79.00 & 65.00 & 57.00 & 49.00 & 49.00 & 60.00 \\
\hline & Evaporation Rate (mm) & 400.00 & 620.00 & 745.00 & 812.00 & 950.00 & 700.00 & 651.00 & 550.00 & 500.00 & 500.00 & 400.00 & 401.00 & 602.00 \\
\hline \multirow{4}{*}{$\begin{array}{l}\text { Previous } \\
(1985-1990)\end{array}$} & Temperature $\left({ }^{\circ} \mathrm{C}\right)$ & 7.00 & 9.00 & 14.00 & 22.00 & 32.00 & 24.00 & 21.00 & 20.00 & 18.00 & 17.00 & 12.00 & 11.00 & 17.00 \\
\hline & Rainfall (mm) & 24.00 & 84.00 & 99.00 & 33.00 & 97.00 & 328.00 & 497.00 & 589.00 & 284.00 & 48.00 & 21.00 & 15.00 & 177.00 \\
\hline & Humidity (\%) & 58.00 & 69.00 & 68.00 & 61.00 & 59.00 & 64.00 & 92.00 & 84.00 & 78.00 & 64.00 & 56.00 & 56.00 & 67.00 \\
\hline & Evaporation Rate (mm) & 370.00 & 580.00 & 634.00 & 745.00 & 812.00 & 620.00 & 570.00 & 460.00 & 430.00 & 430.00 & 380.00 & 395.00 & 536.00 \\
\hline \multirow{4}{*}{$\begin{array}{l}\text { Changes } \\
(1985-2010)\end{array}$} & Temperature $\left({ }^{\circ} \mathrm{C}\right)$ & -3.00 & 1.00 & 2.00 & 2.00 & 5.00 & 3.00 & 3.00 & 3.00 & 3.00 & 3.00 & 2.00 & 1.00 & 2.00 \\
\hline & Rainfall (mm) & -12.00 & -16.00 & -23.00 & -20.00 & -21.00 & -67.00 & -11.00 & -23.00 & -22.00 & -17.00 & -9.00 & -6.00 & -21.00 \\
\hline & Humidity (\%) & -6.00 & -5.00 & -4.00 & -5.00 & -8.00 & -6.00 & -11.00 & -5.00 & -13.00 & -8.00 & -8.00 & -8.00 & -7.00 \\
\hline & Evaporation Rate (mm) & 30.00 & 40.00 & 111.00 & 67.00 & 138.00 & 80.00 & 81.00 & 90.00 & 70.00 & 70.00 & 20.00 & 6.00 & 67.00 \\
\hline \multirow{4}{*}{$\begin{array}{l}\text { Annual } \\
\text { Changes }\end{array}$} & Temperature $\left({ }^{\circ} \mathrm{C}\right)$ & -0.15 & 0.05 & 0.10 & 0.10 & 0.25 & 0.15 & 0.15 & 0.15 & 0.15 & 0.15 & 0.10 & 0.05 & 0.10 \\
\hline & Rainfall (mm) & -0.64 & -0.78 & -1.14 & -1.02 & -1.05 & -3.33 & -0.53 & -1.16 & -1.11 & -0.84 & -0.43 & -0.30 & -1.03 \\
\hline & Humidity (\%) & -0.30 & -0.23 & -0.20 & -0.23 & -0.40 & -0.30 & -0.53 & -0.25 & -0.65 & -0.38 & -0.38 & -0.38 & -0.35 \\
\hline & Evaporation Rate (mm) & 1.50 & 2.02 & 5.57 & 3.35 & 6.90 & 4.00 & 4.03 & 4.50 & 3.49 & 3.49 & 1.00 & 0.28 & 3.34 \\
\hline
\end{tabular}


Humidity: Due to climate change impacts the average annual humidity decreased at 0.35 percent a year (Table 2 ). The annual average humidity decreased about 7 percent during 1985-2010 - it was 67 percent during 1985-1990 but decreased to 60 percent by 2005-2010 (Table 2). The two study periods' data analysis suggests that humidity varied between 86 percent in dense oak forest and 64 percent in south-facing barren land.

Evaporation Loss: The increasing average temperature $\left(0.10{ }^{\circ} \mathrm{C} \mathrm{a}^{-1}\right)$ accelerated the evaporation loss at a rate of $3.34 \mathrm{~mm} \mathrm{a}^{-1}$ (Table 2). During 1985-1990 the average annual evaporation loss was estimated at $536 \mathrm{~mm}$ whereas during 2005-2010 it increased by about $66 \mathrm{~mm}$ (Table 2). In 20052010 it approached $1072.3 \mathrm{~mm}$ on south-facing barren land and dropped to $559.4 \mathrm{~mm}$ in north-facing oak forest areas of the watershed. It was $786.7 \mathrm{~mm}$ and $811.4 \mathrm{~mm}$ on fairly dense forest / shrub land and agricultural land.

Spatial Distribution of Climatic Parameters and Change: The climate zone maps of the two study periods (1985-1990 and 2005-2010) (Figure $3 \mathrm{a}$ and 3b) derived from climatic parameter distribution indicate that all the existing climatic zones have spread towards higher altitudes due to degrading climatic conditions of the mixed forest, pine forest, and oak forest in the subtropical, temperate, and moist temperate climate zones. The results also show that the rates of climate change are increasing in higher elevations (Figure $3 c$ and $3 d$ ), which dominantly affects the natural vegetation cover throughout the Himalaya up to the snow line $(6000 \mathrm{~m})$. Above the snow line it also affects the snow cover, which could be the major reason for the melting of glaciers. In order to monitor the impacts of climate change on land use patterns, IRS LISS-III and PAN merged data for 1990 and 2010 were analyzed with the land use informatics module.

\subsection{Accelerated Land Use / Land Cover Change through Climate Change}

The land use informatics module consists of comparative land use / land cover mapping for 1990 and 2010 to assess the changes. In order to monitor the dynamics of the land transformation process, satellite image interpretation was conducted using the IRS LISS-III and PAN merged data for the respective years. This exercise revealed that oak and pine forests have decreased by 25 percent $\left(4.48 \mathrm{~km}^{2}\right)$ and 3 percent $\left(0.28 \mathrm{~km}^{2}\right)$ respectively, a decline of such forest cover of $4.76 \mathrm{~km}^{2}$ in the watershed between 1990 and 2010. But the mixed forest had taken the place of oak forest in certain pockets, increasing the mixed forest in the catchment by 18 percent $\left(2.3 \mathrm{~km}^{2}\right)$ during the same period, which reduced the overall loss of forests in the region. This change in forest species, however, is not ecologically advantageous. Oak forest, with its broad leaves and extensive root system, helps control hydrological hazards such as accelerated runoff, erosion, landslides, flash floods, and river-line floods during the monsoon period as well as drought during the nonmonsoon period. As a result, the watershed recorded a total decline of $2.46 \mathrm{~km}^{2}$ or 6 percent forest area between 1990 and 2010 (Table 3 and Figure 3c, 3d). The non-forest area has increased dramatically due to lopping and cutting of trees, accelerated runoff, soil erosion, and growing agricultural activities. The non-forest area includes barren land, riverbeds, and cultivated land. Barren land increased $1.21 \mathrm{~km}^{2}(56$ percent), riverbeds increased $0.78 \mathrm{~km}^{2}$ (52 percent), and cultivated land increased $0.63 \mathrm{~km}^{2}$ (3 percent) during the same period (Table 3 and Figure 3c, 3d). The field survey indicates that the overall accelerating factors of the land use dynamics in the study area can be broadly categorized as dominant factors and supporting factors. Out of the seven types of land use / land cover, five types (oak, pine, mixed, barren, and riverbed) are being affected dominantly by climate change while anthropogenic factors play only a supporting role. Only shrub land and cultivated land are being affected dominantly by anthropogenic factors while climate change plays a supporting role. The expansion of mixed forest land occurred due to upslope shifting of existing forest species because the climate of upslope areas has been getting warmer in recent decades.

\subsection{Increasing Geohydrological Hazards}

Land use / land cover change due to climate change also accelerates geohydrological hazards in the Himalaya. Deforestation and land degradation trigger high runoff, flash floods, river-line floods, soil erosion, and non-seismic landslides during the monsoon season. These hydrological hazards are mainly responsible for several socioeconomic consequences (cultivated land degradation, infrastructure loss, human casualties, loss of transmission lines, and so on) in the mountains.

Excessive Flood Runoff: Flood runoff means the flowing off of watershed precipitation through a surface channel. The comparative hydrological evaluation of the two study periods suggests that the monsoon flood runoff (June to September) is increasing because of accelerated land use / land cover change due to climate change. Densely forested land with broad-leaved tree species has very high and deforested barren land has very low water retention capacity within their hydrological system. Although high runoff occurs in all monsoon months, maximum monsoon runoff occurs in August due to extreme rainfall (Table 4). Consequently the average monsoon flood runoff in August during the 2005-2010 period was $12351 \mathrm{~s} \mathrm{~s}^{-1} \mathrm{~km}^{-2}$ whereas in the same month during 1985-1990 it was only $1076 \mathrm{I} \mathrm{s}^{-1} \mathrm{~km}^{-2}$ although the rainfall of the latter period was consistently higher from June to September (Table 4). The spatial distribution of flood runoff for 1985-1990 and 2005-2010 is illustrated in Figure 4a. Each monsoonal hydrological hazard in Figure 4 comprises four hazard zones with their respective hazard potential index for 1985-1990 and 2005-2010 in the Dabka watershed of the Himalaya. 


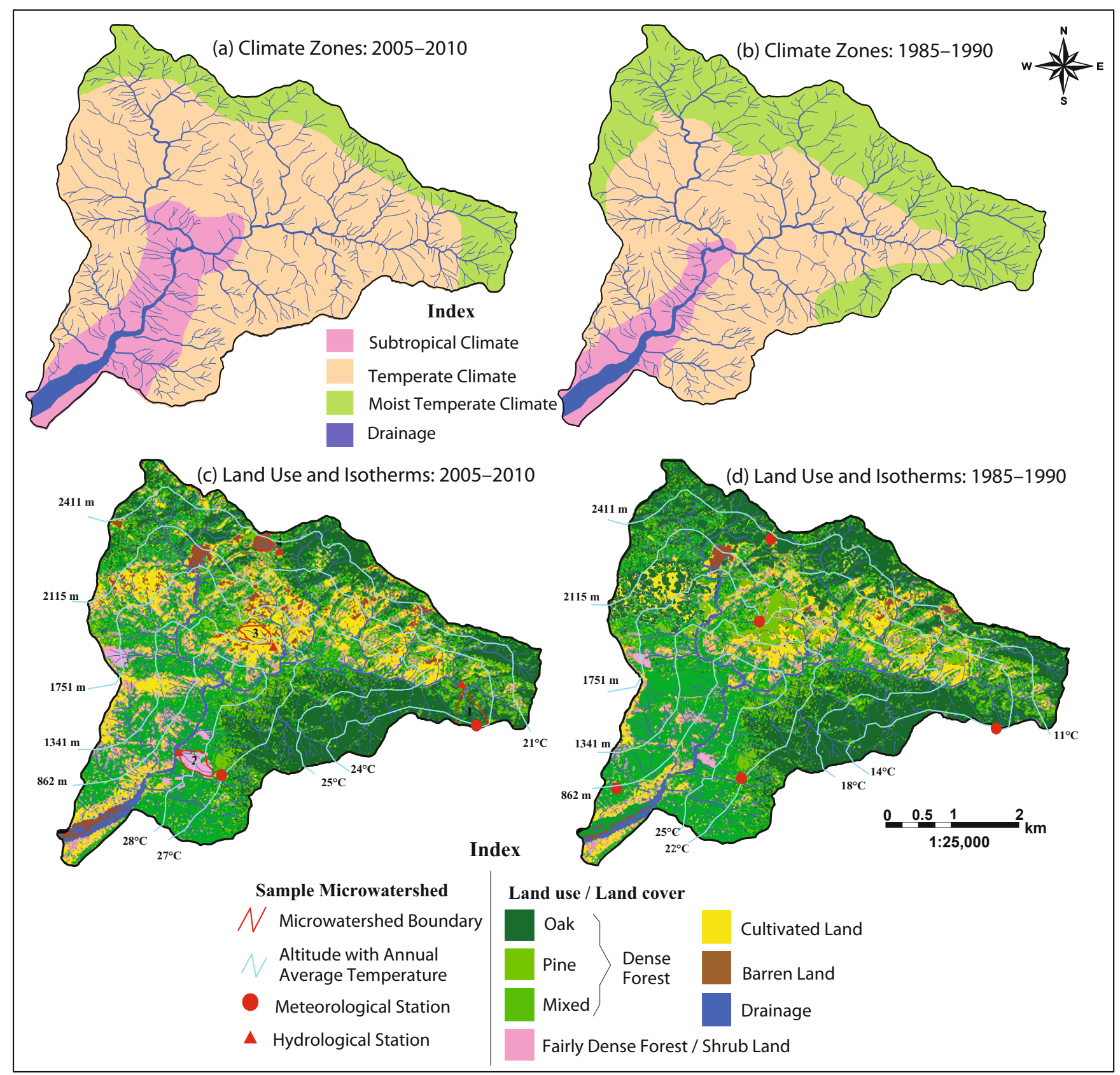

Figure 3. Climate zones (a) and land use (c) for 2010; Climate zones (b) and land use (d) for 1990 in the Dabka watershed Source: Rawat, Tiwari, and Pant 2011.

Accelerated Soil Erosion: Data analysis of the two study periods shows increasing trends of soil erosion (Figure 4b and Table 4) as reflected in the accelerated bed load and suspended and dissolved load transport throughout the study area. In 1985-1990 the total annual rates of bed load and suspended and dissolved loads were estimated at $84.92 \mathrm{t} \mathrm{km}^{-2}$, $47.19 \mathrm{t} \mathrm{km}^{-2}$, and $26.82 \mathrm{t} \mathrm{km}^{-2}$ whereas during the recent study period (2005-2010) these rates increased to $124.50 \mathrm{t} \mathrm{km}^{-2}$, $58.50 \mathrm{t} \mathrm{km}^{-2}$, and $34.50 \mathrm{t} \mathrm{km}^{-2}$ respectively (Table 4). The annual average rate of soil erosion increased in the Dabka watershed from only $0.42 \mathrm{~mm}$ in $1985-1990$ to $0.68 \mathrm{~mm}$ in 2005-2010 (Table 4). Increased soil erosion (Figure 4b and
Table 4) and denudation rates worsen landslides and slope failures in highlands and huge quantities of sediment deposition over the riverbeds cause river-line flood and flash flood hazards in the study area.

Increasing Landslide Hazard: After recording all the existing landslides during fieldwork a spatial distribution and density map of landslides was created through GIS mapping following the grid and isopleth technique (Figure 4c). The map suggests that the current high landslide risk area of the watershed has very high to high density of landslides, which stands at 39 percent $\left(26.93 \mathrm{~km}^{2}\right)$ and 32 percent $\left(22.10 \mathrm{~km}^{2}\right)$ 
Table 3. Land use dynamics in the Dabka watershed

\begin{tabular}{|c|c|c|c|c|c|c|c|c|}
\hline \multirow{2}{*}{$\begin{array}{l}\text { Land Use and Land } \\
\text { Cover Classes }\end{array}$} & \multicolumn{2}{|c|}{ 1985-1990 } & \multicolumn{2}{|c|}{$2005-2010$} & \multicolumn{2}{|c|}{ Change } & \multicolumn{2}{|c|}{ Accelerating Factors of Land Use Dynamics } \\
\hline & $\mathbf{k m}^{2}$ & $\%$ & $\mathbf{k m}^{2}$ & $\%$ & $\mathbf{k m}^{2}$ & $\%$ & Dominant Factor & Supporting Factor \\
\hline 1. Oak Forest & 17.99 & 26.05 & 13.51 & 19.56 & -4.48 & -25 & Climate Change & Anthropogenic \\
\hline 2. Pine Forest & 8.21 & 11.89 & 7.93 & 11.48 & -0.28 & -3 & Climate Change & Anthropogenic \\
\hline 3. Mixed Forest & 13.03 & 18.87 & 15.33 & 22.20 & +2.3 & +18 & Climate Change & Nil \\
\hline Total Forest & 39.23 & 56.81 & 36.77 & 53.24 & -2.46 & -6 & Climate Change & Anthropogenic \\
\hline 4. Shrub Land & 6.38 & 9.24 & 6.22 & 9.01 & -0.16 & -3 & Anthropogenic & Climate Change \\
\hline 5. Barren Land & 2.18 & 3.16 & 3.39 & 4.91 & 1.21 & +56 & Climate Change & Anthropogenic \\
\hline 6. Riverbeds & 1.50 & 2.17 & 2.28 & 3.30 & 0.78 & +52 & Climate Change & Anthropogenic \\
\hline 7. Cultivated Land & 19.77 & 28.63 & 20.40 & 29.54 & 0.63 & +3 & Anthropogenic & Climate Change \\
\hline Total Non-Forest & 29.83 & 43.19 & 32.29 & 46.76 & 2.46 & +8 & Climate Change & Anthropogenic \\
\hline Study Area (Total) & 69.06 & 100.00 & 69.06 & 100.00 & \multicolumn{4}{|c|}{ Climate Change and Anthropogenic Factors } \\
\hline
\end{tabular}

Source: Rawat, Tiwari, and Pant 2011.

of the watershed area, whereas the low risk area is only about 7 percent $\left(4.83 \mathrm{~km}^{2}\right)$ of the watershed area, with low density of landslides. The moderate landslide density area covers about 22 percent of the watershed area. Low and moderate landslide density zones have less than 4 and 4-8 landslides $\mathrm{km}^{-2}$ whereas high to very high landslide density zones have 8-12 and above 12 landslides $\mathrm{km}^{-2}$ (Figure 4c). Comparatively, some twenty years ago landslide density was quite low for all landslide hazard zones.

Increasing Hydrological Hazard Frequency: The integrated monsoon hydro-hazard frequency map generated after overlaying flood, erosion, and landslide hazard maps, shows four hydro-hazard frequency zones in the watershed (Figure 4d). The evaluation of the area statistics for current hydro-hazard frequency shows that 34 percent of the total area of the watershed has very high frequency of hydro-hazards (above 60 events $\mathrm{km}^{-2}$ annually), 21 percent has high frequency of hydro-hazards (40-60 events $\mathrm{km}^{-2}$ annually), 17 percent has moderate frequency of hydro-hazards (20-40 events $\left.\mathrm{km}^{-2}\right)$, and 28 percent has low frequency of hydro-hazards (below 20 events $\mathrm{km}^{-2}$ ). This frequency was quite low in all four zones during 1985-1990, which suggests an increasing trend of hydro-hazard frequency in the study area. An overall assessment of the watershed found that very high hydrohazard frequency mostly occurred on steep slopes with the lithology of the Lariakantha-Bhumiadhar Formation and along major streams. High-frequency areas are found in moderately steep parts of the watershed and along major tributary streams, whereas moderate and low-frequency areas are confined to dense forests with the lithology of the Krol Formation and human managed landscapes, such as cultivated and pasture lands.

\section{Impacts of Climate Induced Hydrological Hazards on Monsoon Crop Patterns}

Farming is the main source of community food and livelihoods throughout the Himalaya but unfortunately it is also the economic sector most susceptible to climate change. The meteorological data show that agroecology is trending toward a hotter and less humid environment. This is attributed to the fact that climate change affects the two most important conditions for agricultural production: precipitation and temperature. Climate change also indirectly affects agriculture by influencing the emergence and distribution of crop pests and livestock diseases, exacerbating the frequency and distribution of adverse weather conditions, and reducing water supplies and irrigation. Climate change also affects land use dynamics and the frequency of hydrological hazards, which in turn affect agricultural land and production, and thus community food supplies and livelihoods.

\subsection{Increasing Hazard Exposure of Cultivated Land}

Exposure of cultivated land to climate change induced hydrological hazards is assessed through superimposing the land use maps over integrated hydro-hazard maps. The results suggest increasing exposure of cropland to hydrological hazards in recent decades (Table 5). Out of the total (2040 ha) existing cultivated land 13 percent $(265.20 \mathrm{ha})$ is within the low hydrohazard zone, but this number was 56 percent (1107.12 ha) of the total (1977 ha) in 1985-1990. The cultivated land with moderate hydro-hazard exposure covers about 21 percent (428.40 ha) of the total existing cultivated land area, whereas it was about 27 percent (533.79 ha) of the total in 1985-1990.

As high as 40 percent ( 816 ha) of the total existing cultivated land have high hydro-hazard exposure. This number was only about 11 percent $(217.47 \mathrm{ha}$ ) of the total in $1985-$ 1990. The new high exposure cultivated areas are often located along the rivers and streams. Out of the total 2040 ha existing cultivated land, 26 percent (530.40 ha) is within the very high hydro-hazard zone, whereas this number was only about 6 percent (118.62 ha) of the respective total in 19851990. In the study area the very high exposure cultivated lands are mainly rice paddy fields.

\subsection{Cultivated Land Affected by Different Types of Hydrological Hazards}

Agricultural land affected by various geohydrological hazards is analyzed for the period 2005-2010 (Table 6). On 


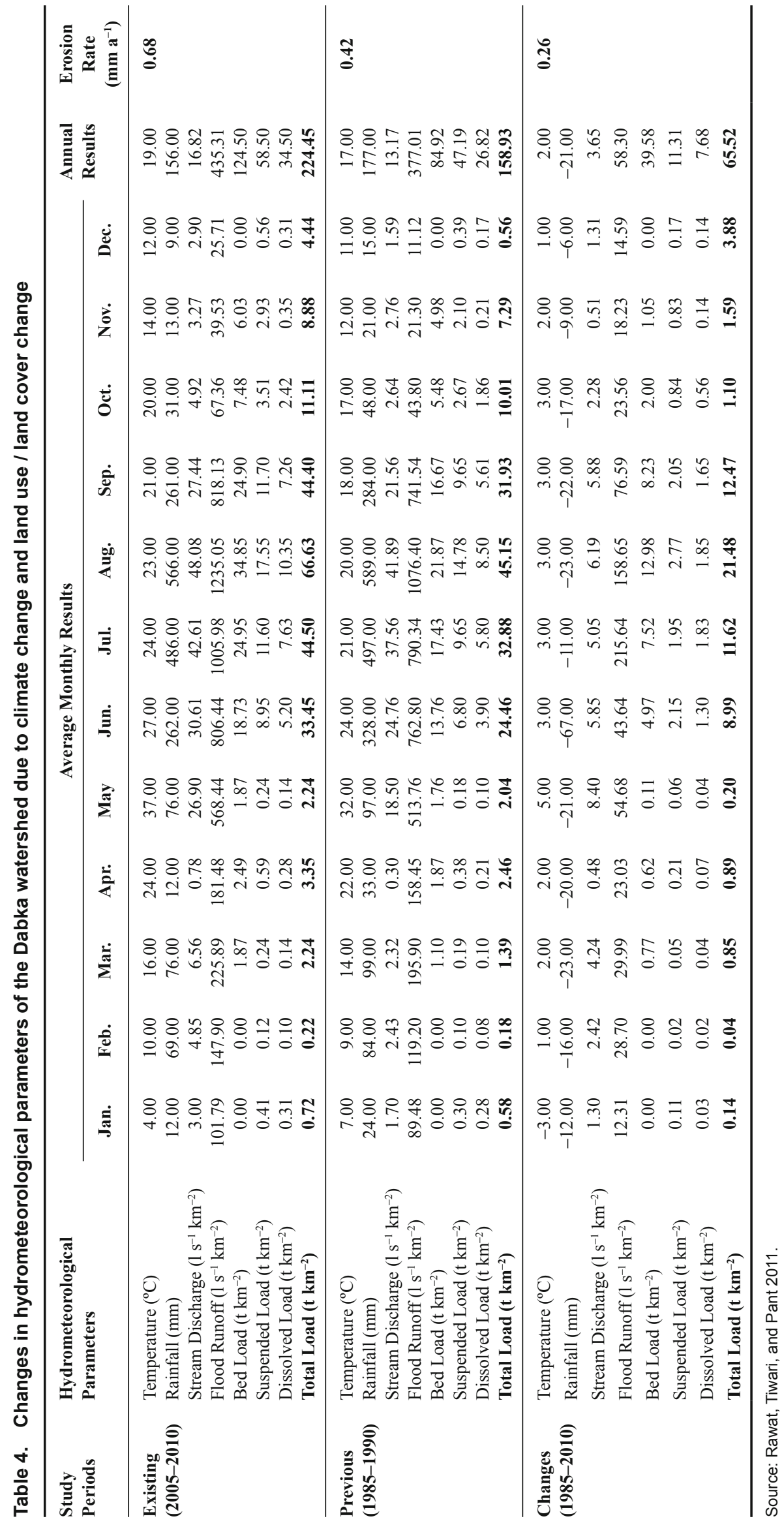




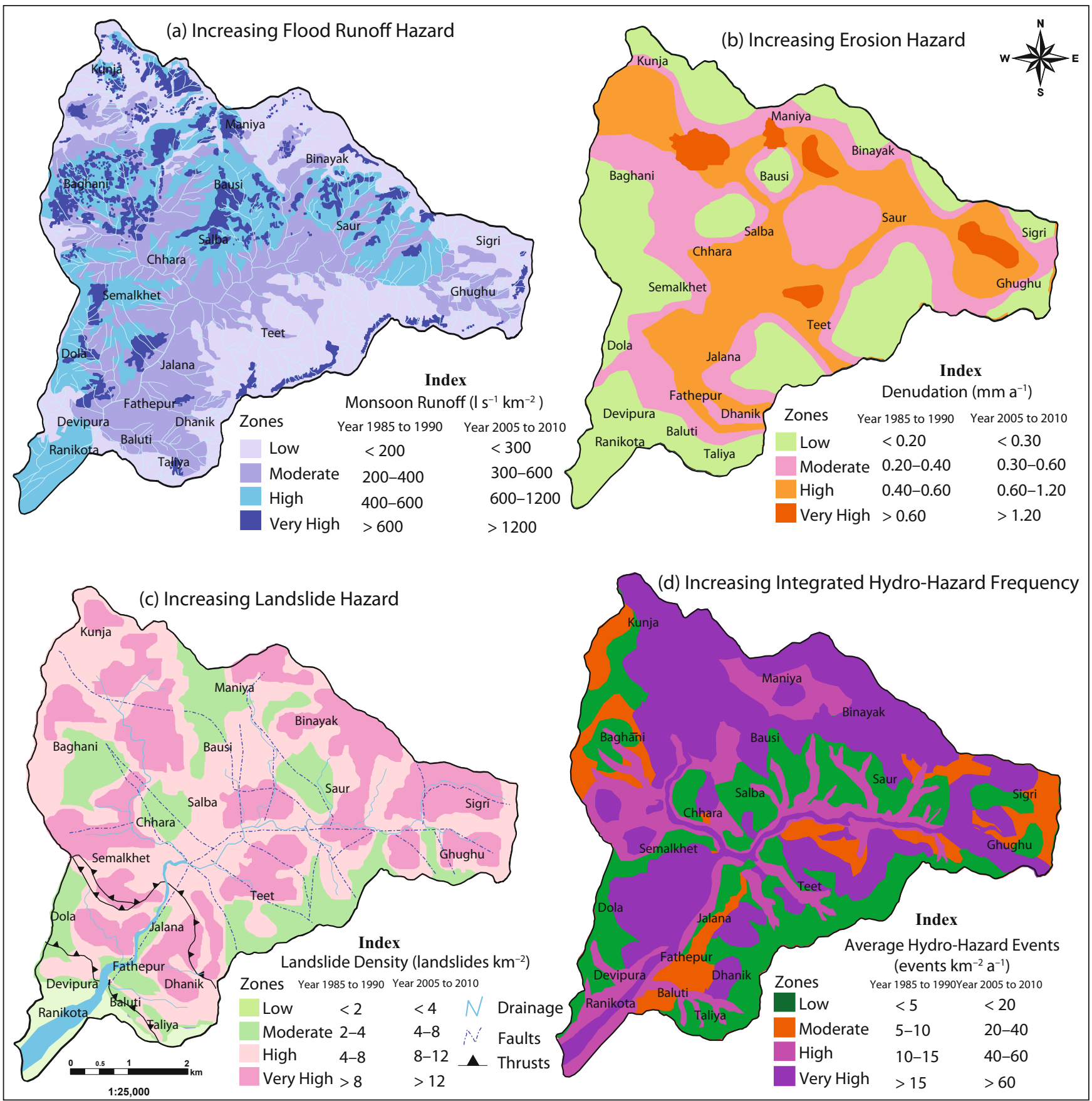

Figure 4. Monsoonal hydrological hazards in the Dabka watershed: Increasing flood runoff hazard (a); Increasing erosion hazard (b); Increasing landslide hazard (c); Increasing integrated hydro-hazard frequency (d)

Source: Rawat, Tiwari, and Pant 2011.

average about 443 ha cultivated land were affected each year, which accounts for about 22 percent of the total existing cultivated land. About 7 percent (149.73 ha) of cultivated land was affected by flash floods or high runoff hazards. An additional 3 percent $(65.20$ ha) was affected by landslides, 6 percent ( $130.57 \mathrm{ha}$ ) by soil erosion, and 5 percent ( $97.73 \mathrm{ha}$ ) by river-line floods. The spatial distribution of the affected cultivated land during 2005-2010 indicates that flash floods and river-line floods mostly affected high-fertility irrigated land because such lands are often located along the rivers and streams and are highly vulnerable to both types of floods. Landslides affected mostly non-irrigated cultivated land because such lands are mainly located in moderate to steep slope areas of the hills, which are highly vulnerable to landslide hazards. Erosion hazards are also a major factor affecting agricultural land in the Himalaya mountain area and affect irrigated and non-irrigated land equally. 
Table 5. Increasing hazard exposure of cultivated land during 1985-2010 in the Dabka watershed

\begin{tabular}{lccccc}
\hline $\begin{array}{l}\text { Integrated } \\
\text { Hydro-Hazard }\end{array}$ Zones & \multicolumn{4}{c}{ Cultivated Land } \\
\cline { 2 - 3 } & \multicolumn{2}{c}{$\mathbf{1 9 8 5}-\mathbf{1 9 9 0}$} & & $\mathbf{2 0 0 5 - 2 0 1 0}$ \\
\cline { 2 - 3 } \cline { 5 - 6 } & ha & $\mathbf{\%}$ & & ha & \% \\
\hline Low & 1107.12 & 56 & & 265.20 & 13 \\
Moderate & 533.79 & 27 & & 428.40 & 21 \\
High & 217.47 & 11 & & 816.00 & 40 \\
Very High & 118.62 & 6 & 530.40 & 26 \\
Total & $\mathbf{1 9 7 7 . 0 0}$ & $\mathbf{1 0 0}$ & $\mathbf{2 0 4 0 . 0 0}$ & $\mathbf{1 0 0}$ \\
\hline
\end{tabular}

\subsection{Decreasing Yields}

The analysis shows that although the rate of decrease varied by crops, on average yields of monsoon crops decreased 28 percent between 1985 and 2010, whereas the total population of the study area increased by 37 percent during the same time period (Table 7).
Rice: Rice is a major monsoon crop but the yield of this crop decreased on average by 1.45 percent each year and 29 percent in total between 1985 and 2010. The 2005-2010 unit yield was about $1200 \mathrm{~kg} \mathrm{ha}^{-1}$ whereas it was $1700 \mathrm{~kg}$ $\mathrm{ha}^{-1}$ in 1985-1990, even though the area for rice cropping had increased to 674 ha from 559 ha. Farmers prefer humid lowland areas for rice production. Such type of land is often along the rivers and streams and has high exposure to river-line floods, flash floods, and high runoff hazards.

Madir: This is a subsidiary crop of rice. The local people use its grain as a staple food in hilly areas. It grows in moderately high to high land areas and requires no irrigation. Its yield decreased at 1.55 percent annually. Farmers had increased the cropping area for madir to 226 ha from 209 ha in 1985-1990. These areas are highly prone to erosion and landslide hazards but have moderate exposure to flood hazards.

Maduwa: This is a subsidiary crop of wheat. People use its grain for flour. It also grows in moderately high to high land areas where irrigation is unavailable. Its yield decreased by 1.65 percent annually. In 2005-2010 it covered about 175 ha

Table 6. Cultivated land affected by geohydrological hazards during the monsoon period in the Dabka watershed

\begin{tabular}{|c|c|c|c|c|c|c|c|}
\hline \multirow[t]{2}{*}{ Year } & \multirow{2}{*}{$\begin{array}{c}\text { Total Cultivated } \\
\text { Land }\end{array}$} & \multicolumn{5}{|c|}{ Cultivated Land Affected by Different Types of Geohydrological Hazards (ha) } & \multirow{2}{*}{$\begin{array}{c}\% \text { of Tota } \\
\text { Cultivated } \\
\text { Land }\end{array}$} \\
\hline & & $\begin{array}{c}\text { Flash Flood or } \\
\text { High Runoff }\end{array}$ & $\begin{array}{l}\text { River-Line } \\
\text { Flood }\end{array}$ & $\begin{array}{c}\text { Soil } \\
\text { Erosion }\end{array}$ & $\begin{array}{c}\text { Landslides and } \\
\text { Slumps }\end{array}$ & $\begin{array}{l}\text { Total of All } \\
\text { Hazards }\end{array}$ & \\
\hline 2005 & 2040 & 119.78 & 78.25 & 104.33 & 52.16 & 354.52 & 17 \\
\hline 2006 & 2040 & 165.19 & 107.23 & 143.93 & 71.48 & 487.83 & 24 \\
\hline 2007 & 2040 & 155.53 & 101.43 & 136.21 & 67.62 & 460.79 & 23 \\
\hline 2008 & 2040 & 137.17 & 89.84 & 119.78 & 59.89 & 406.68 & 20 \\
\hline 2009 & 2040 & 89.84 & 58.93 & 78.25 & 39.61 & 266.63 & 13 \\
\hline 2010 & 2040 & 230.87 & 150.70 & 200.93 & 100.46 & 682.96 & 33 \\
\hline \multicolumn{2}{|c|}{ Average Annual } & 149.73 & 97.73 & 130.57 & 65.20 & 443.24 & 22 \\
\hline \multicolumn{2}{|c|}{$\%$ of Existing Cultivated Land } & 7 & 5 & 6 & 3 & 22 & - \\
\hline
\end{tabular}

Table 7. Average yield of monsoon crops and population growth 1985-2010 in the Dabka watershed

\begin{tabular}{|c|c|c|c|c|c|c|c|c|c|c|}
\hline \multirow{3}{*}{$\begin{array}{l}\text { Monsoon } \\
\text { Crop }\end{array}$} & \multicolumn{6}{|c|}{ Crop Production } & \multicolumn{4}{|c|}{ Population } \\
\hline & \multicolumn{2}{|c|}{ Sowed Area (ha) } & \multicolumn{2}{|c|}{ Yield (kg ha $\left.{ }^{-1}\right)$} & \multicolumn{2}{|c|}{ Change in Yield (\%) } & \multicolumn{2}{|c|}{ Total Population } & \multicolumn{2}{|c|}{ Growth Rate (\%) } \\
\hline & 1985-1990 & 2005-2010 & 1985-1990 & $2005-2010$ & 1985-2010 & Annual & 1985-1990 & $2005-2010$ & 1985-2010 & Annual \\
\hline Rice & 559 & 674 & 1700 & 1200 & -29 & -1.45 & 1075 & 1482 & 37 & 2 \\
\hline Millets & 183 & 78 & 2100 & 1400 & -33 & -1.65 & & & & \\
\hline Maize & 189 & 210 & 2400 & 1600 & -33 & -1.65 & & & & \\
\hline Maduwa & 209 & 175 & 1800 & 1200 & -33 & -1.65 & & & & \\
\hline Madir & 209 & 226 & 1600 & 1100 & -31 & -1.55 & & & & \\
\hline Soybean & 140 & 152 & 1700 & 1200 & -29 & -1.45 & & & & \\
\hline Pulses & 150 & 137 & 900 & 600 & -33 & -1.65 & & & & \\
\hline Groundnut & 148 & 183 & 1100 & 700 & -36 & -1.80 & & & & \\
\hline Ginger & 157 & 151 & 15,200 & 13,800 & -9 & -0.45 & & & & \\
\hline Turmeric & 33 & 54 & 14,600 & 13,000 & -11 & -0.55 & & & & \\
\hline Beans & 48 & 65 & 1300 & 900 & -31 & -1.55 & & & & \\
\hline Total & 1977 & 2040 & & & & & & & & \\
\hline Average & & & & & -28 & -1.40 & & & & \\
\hline
\end{tabular}


land but in 1985-1990 the cropping area was 209 ha. These areas are highly prone to erosion and landslide hazards.

Maize: Maize grows in highland areas and hills. Its cropping area also increased. Its yield decreased by 1.65 percent annually. The areas where this crop is grown are also highly prone to erosion and landslide hazards.

Millets: In the past people used millets as much as other food but it has become less popular in recent years. Consequently its cropping area has decreased significantly. Annual yield also decreased by 1.65 percent. This crop grows in higher land areas prone to erosion and landside hazards.

Soybean: This crop is used for oil and also as pulses. Although this crop grows in all types of land, its yield is highest in low land humid areas. Because of its multiple uses local farmers increased its cropping area from 149 to 152 ha though annual yield decreased by 1.45 percent.

Pulses: Rajma, urad, and gahat are the main types of monsoon pulses in the Lesser Himalaya region as well as in the case study area. Gahat grows in high land whereas rajma and urad grow in lowland areas. The yield decreased at an annual rate of 1.65 percent. In recent decades, the areas where pulses are grown are prone to all types of hydrological hazards, including floods, erosion, and landsides.

Groundnut: This crop grows in sandy soils in the hills. People sell it in the markets of the adjoining areas. Farmers increased its cropping area, but yield decreased by $400 \mathrm{~kg}$ $\mathrm{ha}^{-1}$ at an annual rate of 1.80 percent. These areas have moderate to low exposure to hydrological hazards.

Ginger: Yield decreased from 15,200 to $13,800 \mathrm{~kg} \mathrm{ha}^{-1}$ at an annual rate of 0.45 percent. Ginger grows at all altitudes in the Lesser Himalaya region.

Turmeric: Yield decreased by 0.55 percent annually, from 14,600 to $13,000 \mathrm{~kg} \mathrm{ha}^{-1}$.

Beans: Farmers use beans for their own consumption as a vegetable and pulses. Yield decreased from 1300 to $900 \mathrm{~kg}$ $\mathrm{ha}^{-1}$ at an annual rate of 1.55 percent.

\section{Discussion}

Climate change impacts vary depending on the specific geoecosystems of concern. Climate change has some clearly established impacts on agricultural production and poses a great threat to food security around the world (Adams et al. 1998; Lobell and Field 2007; Schmidhuber and Tubiello 2007; Schlenker and Lobell 2010). Rising sea levels and extreme rainfall events cause food security problems in coastal areas (Parry et al. 1999; Porter and Semenov 2005; Slingo et al. 2005). Desert ecosystems have been experiencing extreme droughts and decreasing crop yields due to rising temperature during the last several decades (Rosenzweig and Parry 1994; Fischer et al. 1996; Mearns, Rosenzweig, and Goldberg 1997). Plains ecosystems have exhibited both positive and negative climate change impacts on agricultural production (Adams et al. 1995; Darwin and Kennedy 2000; Schlenker, Hanemann, and Fisher 2006; Lobell and Burke
2010). The most vulnerable mountain ecosystems have been experiencing decreasing crop yields due to land use change and land degradation induced by hydrological hazards that have been accelerated by climate change during the last few decades. The main meteorological phenomena causing intense rainfalls in the region are cloudbursts, stationarity of monsoon troughs, and monsoon depressions (Rawat et al. 2011). Intensive rainfall triggers several hydrological hazards, including flash floods, river-line floods, soil erosion, and non-seismic landslides in monsoon periods. During flash floods especially in the monsoon season, tremendous amounts of erosion occur on the banks of rivers and streams and the floods wash away crops and productive land and later deposit sediments over other agricultural fields and settlements (Rawat et al. 2012). River-line floods erode valley sides and induce landslides and slope instability, which destroy agricultural lands and lead to reduced crop production. Land use / land cover change that has been accelerated by climate change made the situation even worse. Since food supplies in the mountainous Lesser Himalaya region mainly depend on monsoon crop production, it is necessary to develop an integrated and comprehensive land use policy for the region based on the scientific interpretation of the crucial linkages between climate change, land use, and hydrological hazards. As a first step towards mitigating the impacts of climate change and geohydrological hazards on monsoon crop patterns, our research proposes a comprehensive land use plan for the Dabka watershed, which could also be implemented throughout the nonglacial Lesser Himalaya region. It has taken into consideration the parameters of the climate informatics, hydro-informatics, land use informatics and agro-informatics modules. Table 8 summarizes this proposed land use plan.

(1) Conservation, protection, and sustainable development of forest resources are essential for the management of hydrological hazards such as floods, erosion, and landslides in monsoon periods as well as droughts (drying up of natural water springs and streams) in non-monsoon periods. The forest area of the Dabka watershed has been proposed to be increased from the existing $36.77 \mathrm{~km}^{2}$ to $45.00 \mathrm{~km}^{2}$. This increase would be possible by bringing an additional $8.44 \mathrm{~km}^{2}$

Table 8. Proposed land use plan for integrated climate change and hydrological hazard impact mitigation for the Dabka watershed

\begin{tabular}{lrrrrr}
\hline \multirow{2}{*}{$\begin{array}{l}\text { Land Use } \\
\text { Classes }\end{array}$} & \multicolumn{2}{c}{ Existing Area } & & \multicolumn{2}{c}{ Proposed Area } \\
\cline { 2 - 3 } \cline { 6 - 6 } & $\mathbf{k m}^{2}$ & $\mathbf{\%}$ & & $\mathbf{k m}^{2}$ & $\mathbf{\%}$ \\
\hline 1. Dense Forest (Oak, Pine, and Mixed) & 36.77 & 53 & & 45.00 & 65 \\
2. Fairly dense / Shrub land & 6.22 & 9 & & 2.00 & 3 \\
3. Barren Land & 3.39 & 5 & & 0 & 0 \\
4. Cultivated Land & 20.40 & 30 & & 16.30 & 24 \\
5. Riverbed & 2.28 & 3 & & 2.28 & 3 \\
6. Horticulture & 0 & 0 & 3.48 & 5 \\
Total & $\mathbf{6 9 . 0 6}$ & $\mathbf{1 0 0}$ & $\mathbf{6 9 . 0 6}$ & $\mathbf{1 0 0}$ \\
\hline
\end{tabular}


of lopped-forest area or shrub land and agricultural land (with high vulnerability to hydrological hazards) under reforestation programs. These areas currently are severely degraded.

(2) Out of the total $20.40 \mathrm{~km}^{2}$ existing (2005-2010) cultivated land, 22 percent $\left(4.43 \mathrm{~km}^{2}\right)$ are at high risk of hydrological hazards. They are proposed to be converted to shrub land and horticulture areas to reduce the flood runoff and soil erosion, which impact the cultivated land.

(3) With favorable environmental conditions for the production of a variety of fruits and community demand for horticultural development, $3.48 \mathrm{~km}^{2}$ of existing barren, shrub, and cultivated lands that are at high risk of hydrological hazards are recommended to be brought under horticultural development.

(4) As much as $2 \mathrm{~km}^{2}$ of existing barren and cultivated lands are within hazard zones, and therefore highly vulnerable to several types of hydrological hazards due to high rates of runoff and denudation. These areas should be converted to shrub land.

\section{Conclusion}

The Himalaya Mountains have been highly prone to several hydrological hazards. Climate change has increased the hazard events and their severity in the last two decades, particularly through intense rainfall. Flash floods cause severe erosion and sedimentation on productive agricultural land and river-line floods induce landslides and slope instability that also destroy agricultural land and cause reduction in crop yields. This study concludes that climate change has caused the climatic zones to shift towards higher altitudes in the case study area, decreased the area of oak and pine forests, and affected the favorable conditions of the existing land use patterns. Forest degradation has caused a further increase in hydrological hazards (high runoff, flash floods, river-line floods, soil erosion, and landslides) in monsoon periods and affected about 22 percent of cultivated land of the case study area each year. Monsoon crop yields decreased by 1.40 percent annually between 1985 and 2010. The population of the case study area increased by 2 percent each year. The negative correlation between annual crop yields and population growth has led to increased food security risk and the local people have started to seek out other resources to manage the risk and adopted non-farming occupations, which ultimately affect rural livelihoods. It is therefore important to develop a strategy for integrated sustainable development of the Lesser Himalaya region and in particular an integrated and comprehensive land use policy. Based on a comprehensive assessment of climate change and hydrological hazard impacts, this study proposes an alternative land use plan.

\section{Acknowledgments}

This study was part of the multidisciplinary project of the Department of Science and Technology, Government of India
(No. ES/11/599/01, 27/05/2005) on the Geo-Environmental Appraisal of the Dabka Watershed, Kumaun Lesser Himalaya, District Nainital: A Model Study for Sustainable Development, led by Professor Charu C. Pant, Head of the Department of Geology at Kumaun University Nainital. The author thanks Dr. Pradeep K. Goswami from the Department of Geology, Kumaun University Nainital and Dr. P. K. Joshi from Indian Institute of Remote Sensing, Dehradun for their help with the GIS analysis. Thanks to Shri M. S. Bargali, project assistant, for his help during the intensive fieldwork.

\section{References}

Adams, R. M., R. A. Fleming, C. C. Chang, B. A. McCarl, and C. Rosenzweig. 1995. A Reassessment of the Economic Effects of Global Climate Change on US Agriculture. Climatic Change 30 (2): 147-67.

Adams, R. M., B. Hurd, S. Lenhart, and N. Leary. 1998. The Effects of Global Warming on Agriculture: An Interpretative Review. Journal of Climate Research 11 (1): 19-30.

Bisht, M. K. S. 1991. Geohydrological and Geomorphological Investigations of the Dabka Catchment, District Nainital, with Special Reference to Problem of Erosion. Unpublished Ph.D. thesis.

Challinor, A. J., F. Ewert, S. Arnold, E. Simelton, and F. Fraser. 2009. Crops and Climate Change: Progress, Trends, and Challenges in Simulating Impacts and Informing Adaptation. Journal of Experimental Botany 60 (10): 2775-89.

Challinor, A. J., J. M. Slingo, T. R. Wheeler, P. Q. Craufurd, and D. I. F. Grimes. 2003. Toward a Combined Seasonal Weather and Crop Productivity Forecasting System: Determination of the Working Spatial Scale. Journal of Applied Meteorology 42 (2): 175-92.

Challinor, A. J., T. R. Wheeler, P. Q. Craufurd, C. A. T. Ferro, and D. B. Stephenson. 2007. Adaptation of Crops to Climate Change through Genotypic Responses to Mean and Extreme Temperatures. Agriculture, Ecosystems \& Environment 119 (1-2): 190-204.

Challinor, A. J., T. R. Wheeler, P. Q. Craufurd, and J. M. Slingo. 2005. Simulation of the Impact of High Temperature Stress on Annual Crop Yields. Agricultural and Forest Meteorology 135 (1-4): 180-89.

Cline, W. R. 2007. Global Warming and Agriculture: Impact Estimates by Country. Washington, DC: Center for Global Development and Peterson Institute for International Economics.

Cruz, R. A. D. 1992. The Determination of Suitable Upland Agricultural Areas Using GIS Technology. Asian Pacific Remote Sensing Journal 5 (1): 123-32.

Darwin, R. 1999. A Farmer's View of the Ricardian Approach to Measuring Agricultural Effects of Climatic Change. Climatic Change 41 (3-4): 371-411.

Darwin, R., and D. Kennedy. 2000. Economic Effects of $\mathrm{CO}_{2}$ Fertilization of Crops: Transforming Changes in Yield into Changes in Supply. Environmental Modeling and Assessment 5 (3): 157-68.

Easterling, W. E. 1996. Adapting North American Agriculture to Climate Change in Review. Agricultural and Forest Meteorology 80 (1): $1-54$.

Easterling, W. E., P. R. Crosson, N. J. Rosenberg, M. S. McKenny, L. A. Katz, and K. M. Lemon. 1993. Agricultural Impacts of and Responses to Climate Change in the Missouri-Iowa-NebraskaKansas (MINK) Region. Climatic Change 24 (1-2): 23-61.

Fischer, G., K. Frohberg, M. L. Parry, and C. Rosenzweig. 1996. Impacts of Potential Climate Change on Global and Regional Food Production and Vulnerability. In Climate Change and World Food Security, NATO ASI Series, Vol. 137, edited by T. E. Downing. Berlin: Springer.

Fischer, G., M. Shah, F. Tubiello, and H. van Velhuizen. 2005. SocioEconomic and Climate Change Impacts on Agriculture: An Integrated 
Assessment, 1990-2080. Philosophical Transactions of Royal Society B-Biological Sciences 360 (1463): 2067-83.

Hamilton, L. S. 1987. What Are the Impacts of Himalayan Deforestation on the Ganges-Brahmaputra Lowland and Delta? Assumptions and Facts. Mountain Research and Development 7 (3): 256-63.

Hansen, J. W., and J. W. Jones. 2000. Scaling-Up Crop Models for Climate Variability Applications. Agricultural Systems 65 (1): $43-$ 72.

Howden, M., J. F. Soussana, F. Tubiello, N. Chhetri, M. Dunlop, and H. Meinke. 2007. Adapting Agriculture to Climate Change. Proceedings of the National Academy of Sciences of the United States of America 104 (50): 19691-96.

IPCC (Intergovernmental Panel on Climate Change). 2001. Climate Change 2001. In The Scientific Basis: Contribution of Working Group I to the Third Assessment Report of the Intergovernmental Panel on Climate Change, edited by J. T. Houghton, Y. Ding, D. L. Griggs, M. Noguer, P. J. van der Linden, X. Dai, K. Maskell, and C. A. Johnson, 17-43. Cambridge: Cambridge University Press.

2007a. Climate Change 2007. In The Physical Science Basis: Contribution of Working Group I to the Fourth Assessment Report of the Intergovernmental Panel on Climate Change, edited by S. Solomon, D. Qin, M. Manning, Z. Chen, M. Marquis, K. B. Avery, M. Tignor, and H. L. Miller, 24-39. Cambridge: Cambridge University Press.

- 2007b. Summary for Policymakers. In Climate Change 2007: Impacts, Adaptation and Vulnerability. Contribution of Working Group II to the Fourth Assessment Report of the Intergovernmental Panel on Climate Change, edited by M. L. Parry, O. F. Canziani, J. P. Palutikof, P. J. van der Linden, and C. E. Hanson, 7-22. Cambridge: Cambridge University Press.

Iglesias, A., L. Garote, F. Flores, and M. Moneo. 2007. Challenges to Manage the Risk of Water Scarcity and Climate Change in the Mediterranean. Water Resources Management 21 (5): 227-88.

Iglesias, A., C. Rosenzweig, and D. Pereira. 2000. Prediction of Spatial Impacts of Climate in Agriculture in Spain. Global Environmental Change 10 (1): 69-80.

Ives, J. D. 1989. Deforestation in the Himalaya: The Cause of Increased Flooding in Bangladesh and Northern India. Land Use Policy 6 (1): 187-93.

Jain, S. K., S. Kumar, and J. Varghese. 1994. Estimation of Soil Erosion for a Himalayan Watershed Using GIS Technique. Geological Society of London 151 (1): 217-20.

Katz, R. W., and B. G. Brown. 1992. Extreme Events in Changing Climate Variability Is More Important Than Averages. Climatic Change 21 (1): 289-302.

Kostrowicki, J. 1983. Land Use Systems and Their Impact on Environment: An Attempt at Classification. The Geographer 30 (1): 6-14.

Lobell, D. B., and M. B. Burke. 2010. On the Use of Statistical Models to Predict Crop Yield Responses to Climate Change. Agricultural and Forest Meteorology 150 (11): 1443-52.

Lobell, D. B., and C. B. Field. 2007. Global Scale Climate-Crop Yield Relationships and the Impacts of Recent Warming. Environmental Research Letters 2 (1): 1-7.

Mearns, L. O., C. Rosenzweig, and R. Goldberg. 1997. Mean and Variance Change in Climate Scenarios: Methods, Agricultural Applications, and Measures of Uncertainty. Climatic Change 35 (1): 367-96.

Monteith, J. L. 1981. Climatic Variation and the Growth of Crops. Quarterly Journal of the Royal Meteorological Society 107 (454): 749-74.

Parry, M. L., C. Fischer, M. Livermore, C. Rosenzweig, and A. Iglesias. 1999. Climate Change and World Food Security: A New Assessment. Global Environmental Change 9 (1): S51-S67.
Porter, J. R., and M. A. Semenov. 2005. Crop Responses to Climatic Variation. Philosophical Transactions of the Royal Society BBiological Sciences 360 (1463): 2021-35.

Rawat, P. K., P. C. Tiwari, and C. C. Pant. 2011. Climate Change Accelerating Hydrological Hazards and Risks in Himalaya: A Case Study through Remote Sensing and GIS Modeling. International Journal of Geomatics and Geosciences 1 (4): 678-99.

Rawat, P. K., P. C. Tiwari, C. C. Pant, A. K. Sharama, and P. D. Pant. 2011. Modeling of Stream Run-Off and Sediment Output for Erosion Hazard Assessment in Lesser Himalaya: Need for Sustainable Land Use Plan Using Remote Sensing and GIS: A Case Study. Natural Hazards 59 (3): 1277-97.

2012. Spatial Variability Assessment of River-Line Floods and Flash Floods in Himalaya: A Case Study Using GIS. Disaster Prevention and Management 21 (2): 135-59.

Rosenzweig, C., A. Iglesias, G. Fischer, Y. Liu, W. Baethgen, and J. W. Jones. 1999. Wheat Yield Functions for Analysis of Land Use Change in China. Environmental Modeling and Assessment 4 (1): 128-32.

Rosenzweig, C., and M. L. Parry. 1994. Potential Impact of Climate Change on World Food Supply. Nature 367 (24): 133-38.

Scheling, D. 1988. Flooding and Road Destruction in Eastern Nepal (Sun-Koshi). Mountain Research and Development 8 (1): 78-79.

Schlenker, W., W. M. Hanemann, and A. C. Fisher. 2006. The Impact of Global Warming on US Agriculture: An Econometric Analysis of Optimal Growing Conditions. Review of Economics and Statistics 88 (1): $113-25$.

Schlenker, W., and D. B. Lobell. 2010. Robust Negative Impacts of Climate Change on African Agriculture. Environmental Research Letters 5 (1). doi:01401010.1088/1748-9326/5/1/014010.

Schmidhuber, J., and F. N. Tubiello. 2007. Global Food Security under Climate Change. Proceedings of the National Academy of Sciences of the United States of America 104 (50): 19703-08.

Semenov, M. A., and J. R. Porter. 1995. Climatic Variability and the Modeling of Crop Yields. Agricultural and Forest Meteorology 73 (3-4): 265-83.

Shrestha, A. B. 2009. Climate Change in the Hindu Kush-Himalayas and Its Impacts on Water and Hazards. Asia Pacific Mountain Network Bulletin 9: 1-5.

Shrestha, A. B., C. P. Wake, J. E. Dibb, and P. A. Mayewski. 2000. Precipitation Fluctuations in the Nepal Himalaya and Its Vicinity and Relationship with Some Large Scale Climatological Parameters. International Journal of Climatology 20 (3): 317-27.

Singh, S. P., K. I. Bassignana, B. S. Karky, and E. Sharma. 2011. Climate Change in the Hindu Kush-Himalayas: The State of Current Knowledge. Kathmandu: International Centre for Integrated Mountain Development.

Sing, S. K. 2006. Spatial Variability in Erosion in the Brahmaputra Basin: Causes and Impacts. Current Science 90 (9): 1272-76.

Slingo, J. M., A. J. Challinor, B. J. Hoskins, and T. R. Wheeler. 2005. Introduction: Food Crops in a Changing Climate. Philosophical Transactions of the Royal Society B-Biological Sciences 360 (1463): 1983-89.

Tao, F. L., M. Yokozawa, Y. L. Xu, Y. Hayashi, and Z. Zhang. 2006. Climate Changes and Trends in Phenology and Yields of Field Crops in China, 1981-2000. Agricultural and Forest Meteorology 138 (1): 82-92.

Tiwari, P. C. 2000. Land Use Changes in Himalaya and Their Impact on the Plains Ecosystem: Need for Sustainable Land Use. Land Use Policy 17 (2): 101-11.

Valdiya, K. S., and S. K. Bartarya. 1989. Problem of Mass-Movement in a Part of Kumaun Himalaya. Current Science 58 (9): 486-91.

Wheeler, T. R., P. Q. Craufurd, R. H. Ellis, J. R. Porter, and P. V. V. Prasad. 2000. Temperature Variability and the Yield of Annual Crops. Agriculture, Ecosystems \& Environment 82 (1-3): 159-67.

Open Access This article is distributed under the terms of the Creative Commons Attribution License which permits any use, distribution, and reproduction in any medium, provided the original author(s) and source are credited. 